\title{
Prevalence of resistance phenotypes in Staphylococcus aureus and coagulase-negative isolates of venous ulcers of primary healthcare patients
}

\author{
Marlene Andrade Martins ${ }^{[1]}$, Silvana de Lima Vieira dos Santos ${ }^{[1]}$, Lara Stefânia Netto de Oliveira Leão ${ }^{[2]}$, \\ Nayara Portilho Araújo ${ }^{[3]}$ and Maria Márcia Bachion ${ }^{[1]}$
}

[1]. Programa de Pós-Graduação em Ciências da Saúde, Universidade Federal de Goiás, Goiânia, GO. [2]. Laboratório Bacteriologia Médica, Instituto de Patologia Tropical e Saúde Pública, Universidade Federal de Goiás, Goiânia, GO. [3]. Secretaria Municipal de Saúde de Goiânia, Prefeitura Municipal de Goiânia, Goiânia, GO.

\section{ABSTRACT}

Introduction: In venous ulcers, the presence of Staphylococcus aureus and coagulase-negative staphylococcus resistance phenotypes can aggravate and limit the choices for treatment. Methods: Staphylococcus isolated from 69 patients (98 ulcers) between October of 2009 and October of 2010 were tested. The macrolide, lincosamide, streptogramin B $\left(\mathrm{MLS}_{\mathrm{B}}\right)$ group resistance phenotype detection was performed using the $D$-test. Isolates resistant to cefoxitin and/or oxacillin (disk-diffusion) were subjected to the confirmatory test to detect minimum inhibitory concentration (MIC), using oxacillin strips (E-test ${ }^{\circledR}$ ). Results: The prevalence of $S$. aureus was $83 \%$, and $15 \%$ of coagulase-negative staphylococcus (CoNS). In addition were detected $28 \%$ of methicillin-resistant Staphylococcus aureus (MRSA) and $47 \%$ of methicillin-resistant coagulase-negative staphylococcus (MRCoNS). Among the S. aureus, $69.6 \%$ were resistant to erythromycin, $69.6 \%$ to clindamycin, $69.6 \%$ to gentamicin, and $100 \%$ to ciprofloxacin. Considering the MRSA, $74 \%$ were highly resistant to oxacillin, MIC $\geq 256 \mu \mathrm{g} / \mathrm{mL}$, and the $\mathrm{MLS}_{\mathrm{B}} \mathrm{c}$ constitutive resistance predominated in $65.2 \%$. Among the 20 isolates sensitive to clindamycin, 12 presented an inducible $\mathrm{MLS}_{\mathrm{B}}$ phenotype. Of the MRCoNS, $71.4 \%$ were resistant to erythromycin, ciprofloxacin and gentamicin. Considering the isolates positive for $\beta$-lactamases, the MIC breakpoint was between 0.5 and $2 \mu \mathrm{g} / \mathrm{mL}$. Conclusions: The results point to a high occurrence of multi-drug resistant bacteria in venous ulcers in primary healthcare patients, thus evidencing the need for preventive measures to avoid outbreaks caused by multi-drug resistant pathogens, and the importance of healthcare professionals being able to identifying colonized versus infected venous ulcers as an essential criteria to implementing systemic antibacterial therapy.

Keywords: Methicillin-resistant Staphylococcus aureus. Drug resistance bacterial. Varicose ulcer. Primary health care.

\section{INTRODUCTION}

Venous ulcers are the most common type of wound affecting the lower limbs. The ulcers have multi-factor causes, are recurrent, and do not settle easily ${ }^{1}$. The chronic exposure of these ulcers to the environment, associated with the intrinsic factors of the patient, predisposes the onset of infectious processes that worsen the prognosis for cure ${ }^{2}$. Within this context, the healthcare professionals treating these wounds must have the necessary clinical judgment to evaluate the possibility of infection.

Among the many potential infectious agents present in these wounds, from an epidemiological perspective, Staphylococcus aureus and Staphylococcus coagulase-negative are of significant clinical interest as these pathogens are commonly found in skin and soft tissue infections ${ }^{3}$. The resistance phenotypes in these microorganisms, when present in venous ulcers, is an important health condition due to the pathogenicity involved and also the many virulence factors affecting the therapeutic process ${ }^{4}$.

The possibility of multi-drug resistant agents (MDROs) is also a problem. Studies in different countries or regions, point to a growing prevalence of these pathogens $s^{5-8}$.

Address to: Marlene Andrade Martins. Av. Milão Q 10 LT 01, Condomínio Turquesa Torre 4 Residencial Eldorado, 74367-635 Goiânia, GO, Brasil.

Phone: 5562 9966-9965

e-mail: marlenianapower@hotmail.com

Received in 13/03/2012

Accepted in 30/10/2012
Within this context, particular emphasis is given to methicillinresistant Staphylococcus aureus (MRSA) and methicillin-resistant coagulase-negative Staphylococcus (MRCoNS), as well as those susceptible to methicillin: methicillin-sensitive Staphylococcus aureus (MSSA) and methicillin-sensitive coagulase-negative Staphylococcus (MSCoNS). These microorganisms can present other resistance phenotypes of clinical interest, such as constitutive or inducible resistance to the macrolide, lincosamide, streptogramin $\mathrm{B}\left(\mathrm{MLS}_{\mathrm{B}}\right)$ group ${ }^{9-11}$.

In vascular ulcers, these microorganisms integrate the lesion environment with a significant bioburden ${ }^{12,13}$. Therefore, continuous monitoring of the infectious agents and their susceptibility to antimicrobials is recommended as an important infection control strategy ${ }^{14}$, besides contributing to an effective therapy approach in primary healthcare.

The objectives of the present study were: to verify the prevalence and minimum inhibitory concentration of the isolated (MRSA, MSSA, MRCoNS and MSCoNS) of venous ulcers of primary healthcare patients; evaluate the susceptibility profile of these isolates to antimicrobials; and detect constitutive and inducible $M L S_{B}$ resistance phenotypes.

\section{METHODS}

\section{Setting and ethical considerations}

This sectional, clinical and observational study was performed using a quantitative approach and is part of a broader project named: Avaliação de úlceras venosas de estase no contexto do atendimento ambulatorial na rede municipal de saúde de Goiânia: ampliando as perspectivas (The evaluation of venous stasis ulcers in the context 
of outpatient care in the municipal health network of Goiânia: improving the perspectives), integrated to Rede Goiana de Pesquisa em Avaliação e Tratamento de Feridas (Goiânia Network for Research in Wound Evaluation and Treatment), approved by the Research Ethics Committee of Universidade Federal de Goiás (protocol 041/2009). In this city, primary healthcare comprises a low- and mediumcomplexity service network, distributed into seven health districts or administrative regions, which include outpatient clinics and health centers, which provide treatment to individuals with leg ulcers.

The data were obtained between October of 2009 and October of 2010. The following inclusion criteria were established: age equal to or more than 18 years; have at least one venous ulcer for at least six weeks; present at least three clinical signs of infection on the lesion, according to the suggestions of the European Wound Management Association ${ }^{2}$. The exclusion criteria were: having used antimicrobials within 30 days before the specimens were collected.

A total of 69 patients were included in the study, all of which signed the Free and Informed Consent Form. The participants had between one and five lesions, on one or both legs, totaling 98 venous ulcers.

The data were obtained by administering a standardized instrument that includes the list of clinical signs and symptoms for infection proposed by the European Wound Management Association², in addition to a clinical exam and collection of a specimen from the ulcer for microbiological analysis.

\section{Collection of the clinical specimens}

After fully cleaning the ulcers using sodium chloride at $0.9 \%$, the clinical specimens of the lesions were collected using a sterile swab $\left(C^{\circ} P A N^{\circ}\right)$, following the technique proposed by Levine et $\mathrm{al}^{15}$, referenced by Angel et al $^{16}$.

The microbiological analyses were performed following the recommended techniques ${ }^{17-18}$. The quality of the procedures was controlled using standard strains of the American Type Culture Collection (Staphylococcus aureus ATCC ${ }^{\circledR}$ 25923).

\section{Bacterial strains and screening to detect MRSA and MRCONS isolates}

The samples were inoculated in a selective culture medium for Staphylococcus sp., Mannitol salt agar (Himedia $\left.{ }^{\circledR}\right)$. To increase the probability of isolating MRSA and/or MRCoNS, the samples were also cultivated on tryptic soy agar (TSA) Himedia ${ }^{\circledR}$ and tryptic soy broth (TSB) Himedia ${ }^{\circledR}$ supplemented with $4 \% \mathrm{NaCl}$ and $6 \mathrm{mcg} / \mathrm{mL}$ oxacillin ${ }^{19-20}$. The culture media were incubated at $35^{\circ} \mathrm{C}$ for 24 to 48 hours.

The identified microorganisms were tested for 12 antimicrobials using the disk-diffusion technique ${ }^{21}$.The results were interpreted simultaneously to the analysis, according to the criteria established by the Clinical and Laboratory Standards Institute ${ }^{20}$ and the British Society for Antimicrobial Chemotherapy ${ }^{22}$.

\section{Determining the resistance phenotypes}

Specimens that presented resistance to oxacillin or cefoxitin were subjected to the confirmatory test to detect the minimal inhibitory concentration, E-test ${ }^{\circledR}$.

The detection of the inducible $\mathrm{MLS}_{\mathrm{B}}$ phenotype was performed using disk approximation, D-test ${ }^{20}$. In this test, the $2 \mu$ g-clindamycin disk was placed $15 \mathrm{~mm}$ apart from the $15 \mu \mathrm{g}$-erythromycin disk. The flattened inhibition halo around the clindamycin (halo D) classified the result as positive for the inducible phenotype, and, therefore, resistance to clindamycin.

The databank was created using SPSS 17.0 (Statistical Package for the Social Sciences for Windows ${ }^{\circledR}$ ), and descriptive statistics was performed.

\section{RESULTS}

\section{Characteristics of the population}

Of the 69 evaluated patients, 40 (58\%) were male, and 29 (42\%) were female. Of these, 35 (50.7\%) were $\leq 60$ years old, and $34(49.3 \%)$ $>60$ years old. Regarding their social class, 32 (46.4\%) were in social class D according to Brazilian socio-economic classification criterion, from the Brazilian Association of Research Companies (Associação Brasileira de Empresas de Pesquisa - ABEP). Fifty-two (75.4\%) patients has only one lesion, while 17 (24.6\%) had multiple lesions.

\section{Prevalence and susceptibility of the isolated specimens}

Considering the total 98 investigated lesions, 80 (81.7\%) tested positive for Staphylococcus sp. Among these, $83 \mathrm{~S}$. aureus isolates were obtained, 23 (28\%) of which were MRSA and 60 (72\%) MSSA. Regarding the CoNS, 15 isolates were identified, 7 (47\%) of which were resistant (MRCoNS) and 8 (53\%) were sensitive (MSCoNS) to methicillin.

Regarding the MRSA, the analysis of the susceptibility profile revealed resistance to erythromycin (69.6\%), clindamycin (69.6\%), gentamicin $(69.6 \%)$, and ciprofloxacin (100\%) compared to the MSSA. The latter presented the following values: erythromycin (38\%), clindamycin (18\%), tetracycline (28\%), and rifampicin (15\%). MRCoNS showed resistance to erythromycin, ciprofloxacin and gentamicin, with $71.4 \%$ (Table 1).

The drugs with better activity for both isolates, MRSA and MSSA, were mupirocin, linezolid, sulfamethoxazole-trimethoprim, tetracycline and quinupristin/dalfopristin, with sensitivity above $98 \%$. The antimicrobials with the best activity for MRCoNS and MSCoNS were linezolid, mupirocin, quinupristin/dalfopristin and sulfamethoxazole-trimethoprim, with sensitivity above $87.5 \%$.

MRCoNS and MSCoNS isolates with intermediate sensitivity were not identified. On the other hand, among the MRSA, it was found that $4.3 \%$ were sensitive to erythromycin and $17.4 \%$ to oxacillin. Among the MSSA, $25 \%$ were sensitive to erythromycin and ciprofloxacin, $2 \%$ to rifampicin and $4 \%$ to gentamicin.

\section{Characterization of the resistance phenotypes}

All the MRSA and MRCoNS were resistant to cefoxitin (marker), while $95.6 \%$ showed reduced sensitivity to oxacillin. The E-test results evidenced that $17 / 23$ (74\%) MRSA has a high level of resistance to oxacillin $(\geq 256 \mu \mathrm{g} / \mathrm{mL}$ ). The minimum inhibitory concentration (MIC) for the remaining specimens was between 32 and $96 \mu \mathrm{g} / \mathrm{mL}$. It was found that 3/7 (43\%) of MRCoNS had a MIC of $1.5 \mu \mathrm{g} / \mathrm{mL}$ (Table 2).

Regarding the $\mathrm{MLS}_{\mathrm{B}}$ phenotype, the MRSA were highlighted because of their constitutive resistance, in which 15 (65.2\%) isolates presented natural resistance to clindamycin. Between the two clindamycin-sensitive MRSA, only one tested positive in the D-test, and, therefore, also for the inducible phenotype. 
TABLE 1 - Susceptibility of methicillin-resistant Staphylococcus aureus and methicillin-sensitive Staphylococcus aureus and methicillin-resistant coagulase-negative staphylococcus and methicillin-sensitive coagulase-negative Staphylococcus $(f=98)$, isolated from venous ulcers of patients treated in dressing rooms of municipal health centers in Goiânia, to the tested antimicrobials, October of 2009 to October of 2010.

\begin{tabular}{|c|c|c|c|c|c|c|c|c|}
\hline \multirow{3}{*}{ Antimicrobials } & \multicolumn{2}{|c|}{$\begin{array}{c}\text { MRSA } \\
(n=23 / 28 \%)\end{array}$} & \multicolumn{2}{|c|}{$\begin{array}{c}\text { MSSA } \\
(n=60 / 72 \%)\end{array}$} & \multicolumn{2}{|c|}{$\begin{array}{l}\text { MRCoNS } \\
(n=7 / 47 \%)\end{array}$} & \multicolumn{2}{|c|}{$\begin{array}{l}\text { MSCoNS } \\
(n=8 / 53 \%)\end{array}$} \\
\hline & $\mathbf{R}$ & $S$ & $\mathbf{R}$ & $S$ & $\mathbf{R}$ & $\mathbf{S}$ & $\mathbf{R}$ & $S$ \\
\hline & \multicolumn{2}{|c|}{$\%$} & \multicolumn{2}{|c|}{$\%$} & \multicolumn{2}{|c|}{$\%$} & \multicolumn{2}{|c|}{$\%$} \\
\hline Erythromycin & 69.6 & 26.1 & 38.0 & 37.0 & 71.4 & 28.6 & 25.0 & 75.0 \\
\hline Clindamycin & 69.6 & 30.4 & 18.0 & 70.0 & 42.9 & 57.1 & 12.5 & 87.5 \\
\hline Ciprofloxacin & 100.0 & - & 12.0 & 63.0 & 71.4 & 14.3 & 25.0 & 75.0 \\
\hline Linezolid & - & 100.0 & - & 100.0 & - & 100.0 & - & 100.0 \\
\hline Mupirocin & - & 100.0 & - & 100.0 & - & 100.0 & - & 100.0 \\
\hline Oxacillin & 78.3 & 4.3 & - & 100.0 & - & 100.0 & - & 100.0 \\
\hline Cefoxitin & 100.0 & - & - & 100.0 & 100.0 & - & - & 100.0 \\
\hline Tetracycline & - & 100.0 & 28.0 & 72.0 & 28.6 & 71.4 & 50.0 & 50.0 \\
\hline Trimethoprim-sulfamethoxazole & - & 100.0 & 2.0 & 98.0 & 14.3 & 85.7 & 12.5 & 87.5 \\
\hline Rifampicin & 34.8 & 65.2 & 15.0 & 83.0 & 28.6 & 71.4 & 37.5 & 62.5 \\
\hline Gentamicin & 69.6 & 30.4 & - & 96.0 & 71.4 & 28.6 & 25.0 & 75.0 \\
\hline Quinupristin-dalfopristin & - & 100.0 & - & 100.0 & - & 100.0 & - & 100.0 \\
\hline
\end{tabular}

MRSA: methicillin-resistant Staphylococcus aureus; MSSA: methicillin-sensitive Staphylococcus aureus; MRCoNS: methicillin-resistant coagulase-negative staphylococcus; MSCoNS: methicillin-sensitive coagulase-negative Staphylococcus; R: resistant; S: sensitive.

TABLE 2 - Distribution of the minimum inhibitory concentration $(\mu \mathrm{g} / \mathrm{mL})$ of methicillin-resistant Staphylococcus aureus and methicillin-resistant coagulase-negative staphylococcus isolated from the venous ulcers of pateints treated in dressing rooms of municipal health centers in Goiânia, October of 2009 to October of 2010.

\begin{tabular}{|c|c|c|}
\hline MRSA & Number & Percentage \\
\hline \multicolumn{3}{|c|}{$\mathrm{MIC} \mu \mathrm{g} / \mathrm{mL}$} \\
\hline 256 & 17 & 74.0 \\
\hline 32 & 3 & 13.1 \\
\hline 96 & 1 & 4.3 \\
\hline 64 & 1 & 4.3 \\
\hline 48 & 1 & 4.3 \\
\hline total & 23 & 28.0 \\
\hline \multicolumn{3}{|l|}{ MRCoNS } \\
\hline 1.5 & 3 & 43.0 \\
\hline 2 & 2 & 28.5 \\
\hline 0.5 & 1 & 14.2 \\
\hline 0.75 & 1 & 14.2 \\
\hline total & 7 & 47.0 \\
\hline
\end{tabular}

MRSA: methicillin-resistant Staphylococcus aureus; MRCoNS: methicillin-resistant coagulase-negative staphylococcus; MIC: minimum inhibitory concentration.
Among the MRCoNS, only one isolate was positive for the MLS ${ }_{B}$ i phenotype and another for the $\mathrm{MLS}_{\mathrm{B}} \mathrm{c}$ phenotype (Table 3).

The highlight regarding the MSSA was their inducible resistance. Considering the 20 clindamycin-sensitive isolates, $12(20 \%)$ presented inducible $M L S_{B}$ phenotype.

Constitutive resistance was found in only one MSSA and one MSCoNS isolate. No inducible resistance was observed among the MSCoNS, and $75 \%$ of these bacteria were sensitive to both erythromycin and clindamycin.

\section{DISCUSSION}

This is the first study that analyzes the resistance phenotypes of microorganisms isolated from venous ulcers of individuals treated at primary healthcare services in Goiânia, State of Goiás, Brazil.

The present study results show high prevalence of $S$. aureus (83\%) in venous ulcers. In a study performed in Goiânia, State of Goiás, Brazil, involving patients with leg ulcers (including venous, diabetic and traumatic ulcers) treated in dressing rooms, $S$. aureus was the most frequent bacteria $(65 \%)^{23}$. A high bioburden of this pathogen has been reported for chronic lesions, and this is consensual in literature. Staphylococcus aureus is part of the normal skin microbiota, and, therefore, they are frequently found in wounds ${ }^{12,23}$. However, the association of the patient's intrinsic factors and the increase in the microbial load predispose infection ${ }^{1}$.

Among the isolated $S$. aureus, there was a $28 \%$ prevalence of MRSA, whereas for MSSA the prevalence was $72 \%$. We found several studies regarding the occurrence of microorganisms on chronic wounds or samples from skin and soft tissue lesions; however, the frequency of pathogens on venous ulcers is not specified, which makes any comparison impossible $e^{13,23-24}$.

TABLE 3 - Distribution of the macrolide, lincosamide, streptogramin B phenotype detected for methicillin-sensitive Staphylococcus aureus and methicillin-resistant Staphylococcus aureus and methicillin-sensitive coagulase-negative Staphylococcus and methicillin-resistant coagulase-negative Staphylococcus isolated from venous ulcers of patients treated in dressing rooms of municipal health centers in Goiânia, October of 2009 to October of 2010.

\begin{tabular}{|c|c|c|c|c|c|c|c|c|}
\hline \multirow[b]{2}{*}{$\mathrm{MLS}_{\mathrm{B}}$ resistance phenotype } & \multicolumn{2}{|c|}{ MSSA } & \multicolumn{2}{|c|}{ MRSA } & \multicolumn{2}{|c|}{ MRCoNS } & \multicolumn{2}{|c|}{ MSCoNS } \\
\hline & n & $\%$ & $\mathbf{n}$ & $\%$ & $\mathrm{n}$ & $\%$ & $\mathbf{n}$ & $\%$ \\
\hline Erythromycin-resistant and clindamycin-sensitive, D-test $(+) \mathrm{MLS}_{\mathrm{B}} \mathrm{i}$ inducible resistance & 12 & 20.0 & 1 & 4.4 & 1 & 14.2 & - & - \\
\hline Erythromycin- and clindamycin-resistant- $\mathrm{MLS}_{\mathrm{B}} \mathrm{C}$ constitutive resistance & 1 & 1.7 & 15 & 65.2 & 2 & 28.6 & 1 & 12.5 \\
\hline Erythromycin-resistant and clindamycin-sensitive, D-test (-) MSB & 8 & 13.3 & 1 & 4.4 & 2 & 28.6 & 1 & 12.5 \\
\hline Erythromycin-sensitive and clindamycin-sensitive & 39 & 65.0 & 6 & 26.0 & 2 & 28.6 & 6 & 75.0 \\
\hline
\end{tabular}

MLS $_{B}$; macrolide-lincosamide-streptogramin B; MSSA: methicillin-sensitive Staphylococcus aureus; MRSA: methicillin-resistant Staphylococcus aureus; MRCoNS: methicillin-resistant coagulase-negative staphylococcus; MSCoNS: methicillin-sensitive coagulase-negative Staphylococcus; MSB: macrolide-streptogramin B. 
In a reference outpatient clinic in Manaus and in reference dressing rooms in Goiânia, Brazil, the MRSA prevalence is of, respectively, $15.5 \%$ and $20.5 \%{ }^{23-24}$. Some factors that may contribute to increasing bacterial resistance are the common use of antimicrobial therapy among patients with chronic wounds and the possibility of environment contamination?.

Bacteria producing this multi-drug resistance phenotype can spread rapidly in the environment. A continuous monitoring and preventive measures should be implemented ${ }^{14,25}$.

Monitoring with specimens from hospitals is more common. A study in the United States ${ }^{26}$ found that the MIC of 439 hospital MRSA ranged between 4 and $256 \mu \mathrm{g} / \mathrm{mL}$, and only 18 isolates presented $\mathrm{MIC} \leq 64 \mu \mathrm{g} / \mathrm{mL}$.

MRSA is known to be a pathogen of healthcare-associated infections (HCAls) and has been associated with the resistance to methicillin and other drugs. The multi-drug resistance of the hospital MRSA isolates has also been verified in other studies, however in strains obtained from hospitals ${ }^{25-27}$.

All the MRSA isolated in this study were resistant to cefoxitin on the antibiogram (marker) and confirmed by the E- test ${ }^{\oplus}$. Most isolates $(74 \%)$ showed a high resistance level to methicillin, with an $\mathrm{MIC} \geq 256 \mu \mathrm{g} / \mathrm{mL}$. The MIC of the remaining isolated ranged between 32 and $96 \mu \mathrm{g} / \mathrm{mL}$.

Methicillin is a penicillin resistant to the action of penicillinases and the resistance mechanism of $S$. aureus to this drug can be verified by the production of low-affinity penicillin binding proteins (PBP) or by the hyperproduction of $\beta$-lactamases. Classic MRSA strains are associated with the production of PBP2a or mecA gene mediated PBP2 ${ }^{20,28}$.

There is a scarcity of studies on Staphylococcus sp. isolated from venous ulcers of patients treated in outpatient clinics in Brazil as well as in other countries. On the other hand, the prevalence of the identified pathogens ranges significantly in the health centers of different countries and in the same region ${ }^{26-31}$. Different services have different conditions, and, for this reason, comparisons are not pertinent. In addition to this difficulty, a variety of methods used are used in the studies ${ }^{12-13}$. However, it should be observed that most studies regarding these microorganisms are performed in a hospital setting ${ }^{26-27}$.

Few studies investigate the presence of CoNS in the venous ulcers of primary healthcare patients. The approach to this group of microorganisms is another original contribution made by the present study. A survey in the databases found many studies with CoNS from blood samples and many oxacillin-resistance strains could present the mecA gene ${ }^{31}$.

Despite the identification of low frequency of coagulase-negative Staphylococcus among these microorganisms, it was observed there was an increased in MRCoNS isolates. MDROs microorganisms were identified in the study. The co-existence of $\beta$-lactams-resistant strains as well as the $\mathrm{MLS}_{B}$ group is evidence of this result. This fact is of great concern, and requires rigor from healthcare professionals in the implementation of contact precaution measures, with the purpose to avoid the dissemination of pathogens with multiple resistance phenotypes.

MSSA and MSCoNS were both $100 \%$ sensitive to this marker. Cefoxitin is recommended as a phenotypic marker because it predicts mecA gene mediated methicillin resistance ${ }^{20,32}$.
Multi-drug resistant microorganisms have been identified in people with skin and soft tissue infections, in the hospital and other health care service environments ${ }^{14}$. MRSA is referred to as an endemic nosocomial pathogen, with an observed increasing prevalence rate ${ }^{5,27}$. A study conducted in outpatient clinics in the United States indicated an increase in MRSA isolates obtained from the community for this type of infection ${ }^{3}$.

The isolates recovered from hospitals sets, present an increase in $\mathrm{MRCONS}^{33}$. The present study found high prevalence rates for MRCoNS $(47 \%)$ in people with venous ulcers treated in the community. This finding, in addition to being pioneer, suggests that the phenomenon of resistance to $\beta$-lactams is not restricted to the hospital setting.

Regarding the susceptibility profile of the MRSA isolated in this study, the results confirmed the resistance to the group of $\beta$-lactams, in addition to the crossed resistance to clindamycin, erythromycin, ciprofloxacin, rifampicin and gentamicin. These results agree with those reported in other countries, however, in studies performed with patients treated at the hospita|28,34.

It was observed that oxacillin-resistant $S$. aureus has an associated resistance to ciprofloxacin (53.1\%), sulfamethoxazole-trimethoprim $(53.5 \%)$ and rifampicin $(24.8 \%)^{25}$. Clindamycin, sulfamethoxazoletrimethoprim, tetracycline and linezolida are choices of oral therapy in cases of mild to moderate infections, due to community MRSA ${ }^{35}$.

The isolates showed a resistance above $69.6 \%$ to the described drugs. In this sense, considering the local population, these agents are not recommended. However, all MRSA isolates $(100 \%)$ were sensitive to mupirocin, linezolid, sulfamethoxazole-trimethoprim, tetracycline and quinupristin/dalfopristin. These are important alternatives for the treatment of infections by MRSA. Though, considering the infection site (skin and soft tissues), it is necessary to evaluate the bioavailability (pharmacokinetic and pharmacodynamics) of the drugs (sulfamethoxazoletrimethoprim and tetracycline), in the treatment for leg ulcers ${ }^{36-37}$.

The oral therapies commonly used to treat community MRSA are tetracycline, rifampicin, clindamycin, linezolida and sulfamethoxazoletrimethoprim. It is recommended that a combined therapy be used when rifampicin is chosen, in order to avoid mutant strains ${ }^{28,35}$. In this study, $34.8 \%$ of the MRSA and $28.6 \%$ of the MRCoNS isolates were resistant to rifampicin. Among the MSSA isolates, the resistance was $15 \%$, whereas MSCoNS showed a higher resistance rate (37.5\%).

This fact is concerning, considering that there is a limited choice of drugs that are administered orally. Similar results were found in strains obtained in hospitals located in the same city, with $40.7 \%$ resistance to rifampicin ${ }^{25}$. It is presumed that the prevalence of rifampicin-resistant strains has increased in the outpatient health service settings.

Further studies are needed to effectively support the use of antimicrobials at some time during the treatment. However, if necessary, the indication must consider the signs and symptoms of infections, and not only the colonization. This recommendation can avoid the dissemination of multi-drug resistant bacteria ${ }^{14,38}$.

The MSSA were sensitive to most of the evaluated antimicrobials, except for erythromycin. All isolates $(100 \%)$ were sensitive to mupirocin, linezolid, and quinupristin/dalfopristin. High sensitivity (98\%) to sulfamethoxazole-trimethoprim was also observed.

In Brazil, topic mupirocin is used, in the form of a cream at $2 \%$. It is indicated in the treatment for infected wounds and ulcers, impetigo 
and to eradicate MRSA in the nostrils ${ }^{36}$. The topic use of mupirocin for the decontamination of venous ulcers has not been described ${ }^{35,39}$ nor is it recommended according to a systematic review about the topical indication of this antimicrobial ${ }^{38}$. On the venous ulcer treatment guidelines, the use of topical antibacterial agents can be necessary to reduce the microbial load, but this document does not indicate the class type of the agent ${ }^{39}$.

A study conducted in Brazil found 38\% of MRCoNS isolates, and multi-drug resistance was detected in $86 \%$; however, the $\mathrm{MLS}_{B} \mathrm{i}$ phenotype was not investigated ${ }^{33}$.

Erythromycin (macrolides) and clindamycin (lincosamides) are antimicrobials belonging to the $\mathrm{MLS}_{B}$ group, and are widely recommended to treat staphylococcal infections of the skin and soft tissues, in addition to being an alternative for patients allergic to penicillin ${ }^{19}$. Some of the drugs on this group are of oral use ${ }^{36}$, which facilitates their indication in primary healthcare services. The exception is quinupristin (streptogramin), which in association with dalfopristin should be administered intravenously ${ }^{36}$.

In the present study, $100 \%$ of the S. aureus and CoNS were sensitive to these two streptogramins. However, their administration can cause arthralgia, nausea, vomiting, diarrhea, and exanthema; and they are no longer available in Brazil $^{36}$.

The resistance to macrolides and derivatives in Brazil, along with the group of lincosamides and streptogramins B comprise the $M L S_{B}$ phenotype ${ }^{19}$. These antimicrobials are chemically different but with a similar action mechanism, affecting the ribosomal binding and inhibiting protein synthesis. For the laboratory point of view, this resistance phenotype can be identified on the antibiogram through disk diffusion.

The $\mathrm{MLS}_{\mathrm{B}} \mathrm{C}$ constitutive resistance is coded by the erm gene and appears on the antibiogram as the resistance to erythromycin and clindamycin. The $\mathrm{MLS}_{B} \mathrm{i}$ inducible resistance, on the other hand, appears on the antibiogram as the resistance to erythromycin and sensitivity to clindamycin. To detect the $\mathrm{MLS}_{B} \mathrm{i}$ phenotype, it is necessary to perform a complementary test by disk-approximation (D-test), in which the clindamycin halo is flattened by induction. In this case, this drug is not recommended ${ }^{19}$.

MRSA isolates in this study presented higher prevalence of $\mathrm{MLS}_{B} \mathrm{C}$ resistance (65.2\%) compared to $M_{L} S_{B}$ i. Two isolates, initially sensitive to clindamycin, tested positive on the $D$-test, thus, presenting inducible resistance. Among the MRCoNS, the three $\mathrm{MLS}_{B}$ phenotypes were identified, including one isolate with a positive D-test. These data have great clinical relevance, because when the $\mathrm{MLS}_{B}$ i phenotype is not detected the clindamycin treatment can fail ${ }^{19}$.

The MSSA isolates were predominantly resistant to $\operatorname{MLS}_{B} i(20 \%)$, which reinforces the need to investigate the induced resistance to clindamycin in S. aureus.

Multi-drug resistant bacteria in venous ulcers limit the options for treatment, and can thus predispose to complications in the clinical outcomes. Skin and soft tissue infections, alone, are risk factors for the transmission of MDROs S. aureus and coagulase-negative Staphylococcus in the population ${ }^{6}$. These infections account for most infections by MRSA in the community ${ }^{28}$, which are usually treated in outpatient clinic settings.
The long treatment period, due to factors that affect on the healing process of the ulcers, could predispose a more frequent use of antimicrobial agents, and, thus, contribute to an increase in resistance rates. There is a strong association between the occurrence of a chronic wound and the duration of the empirical antimicrobial therapy ${ }^{7}$. Infection treatment failures within the community have been associated with complication of the infection, as well as the increase in the consumption of antimicrobials in primary healthcare ${ }^{40}$.

The present study finding have clinical and epidemiological relevance, because they evidence the need for contact precaution measures; greater control in cleaning and disinfecting equipment between patients; appropriate hand washing, as well as the use of the recommended individual protection equipment, besides providing a physical appropriate for the procedures, i.e., adequate dressing rooms.

The correct treatment for venous ulcers includes the microbiological testing to identify pathogens ${ }^{38-40}$. A careful indication of antimicrobials should be associated to other therapies that, together, could improve the healing process ${ }^{23}$.

The existence of MDROs pathogens and failures during the treatment are important factors for the patient ${ }^{14}$. The healthcare professional can help prevent infection through specialist healthcare procedures, such as thorough cleaning of the ulcer, applying appropriate coverage, evaluating the ulcer for dressing changes, forwarding to other professionals, and assessing the antimicrobial treatment outcome by evaluating the clinical signs and symptoms.

The identification of multi-drug resistant bacteria, such as S. aureus and coagulase-negative Staphylococcus resistant to methicillin and to the $M_{L S}$ group in outpatients with venous ulcers reveals a panorama about the susceptibility profile of the pathogens that affect this population with chronic wounds. The epidemiological data can contribute with the surveillance systems, in the sense of reviewing the measures that could avoid outbreaks and severe infections on individuals with venous ulcers, besides providing safe healthcare.

\section{CONFLICT OF INTEREST}

The authors declare that there is no conflict of interest.

\section{FINANCIAL SUPPORT}

The present study was funded by Fundação de Apoio à Pesquisa do Estado de Goiás (FAPEG).

\section{ABSTRACT IN PORTUGUESE}

\section{Prevalência de fenótipos de resistência em} Staphylococcus aureus e coagulase negativos isolados de úlceras venosas de pessoas atendidas na atenção primária

Introdução: Em úlceras venosas, a presença de Staphylococcus aureus e coagulase negativo com fenótipos de resistência pode constituir fator agravante e limita as opções terapêuticas. Métodos: Foram avaliados estafilococos isolados de 69 pacientes, representando 98 úlceras no período de outubro de 2009 a outubro de 2010. A detecção fenotípica da resistência ao grupo macrolide, lincosamide, streptogramin $\mathrm{B}\left(\mathrm{MLS}_{\mathrm{B}}\right)$ foi realizada pelo $D$-test. Isolados resistentes a cefoxitina e/ou oxacilina (disco-difusão) foram submetidos ao teste confirmatório para detecção da minimum inhibitory concentration (MIC), empregando fitas de oxacilina (E-test $\left.{ }^{\circledR}\right)$. Resultados: A prevalência de S. aureus foi de $83 \%$ e de $15 \%$ de coagulasenegative staphylococcus (CoNS). Identificou-se $28 \%$ de methicillin-resistant 
Staphylococcus aureus (MRSA) e $47 \%$ de methicillin-resistant coagulasenegative staphylococcus (MRCoNS). Entre o S. aureus, 69,6\% apresentaram resistência a eritromicina, $69,6 \%$ a clindamicina, $69,6 \%$ a gentamicina e $100 \%$ a ciprofloxacina. Setenta e quatro por cento dos MRSA apresentaram elevado nível de resistência a oxacilina, MIC $\geq 256 \mu \mathrm{g} / \mathrm{mL}$, e em $65,2 \%$ predominou a resistência constitutiva $\mathrm{MLS}_{\mathrm{B}} \mathrm{c}$. Dos 20 isolados sensíveis a clindamicina, 12 apresentaram fenótipo $\mathrm{MLS}_{\mathrm{B}}$ induzível. Um total de $71,4 \%$ dos MRCoNS apresentaram resistência a eritromicina, ciprofloxacina e gentamicina. Dos isolados positivos para a enzima $\beta$-lactamases, as MIC tiveram breakpoint entre 0,5 a $2 \mu \mathrm{g} / \mathrm{mL}$. Conclusões: Os resultados sinalizam elevada ocorrência de bactérias multirresistentes em úlceras venosas de pacientes recebendo atenção primária, evidenciando a necessidade de medidas preventivas que evitem surtos causados por patógenos resistentes a múltiplas drogas e a importância dos profissionais em discernir infecção de colonização em úlcera venosa, critério fundamental na indicação antibioticoterapia sistêmica.

Palavras-chaves: Staphylococcus aureus resistente à meticilina. Resistência bacteriana a fármacos. Úlcera varicosa. Atenção primária à saúde.

\section{REFERENCES}

1. Percival S, Cutting K. Microbiology of wound. $1^{\text {nd }}$ edition, CRC Press, Taylor \& Francis Group. 2010; p. 409.

2. European Wound Management Association (EWMA). Position document: Identifying criteria for wound infection. London Medical Education Partnership, Ltd, 2005. p. 1-19.

3. Hersh A, Chambers HF, Maselli JH, Gonzales R. National trends in ambulatory visits and antibiotic prescribing for skin and soft-tissue infections. Arch Intern Med 2008; 168:1585-1591.

4. Gordon RJ, Lowy FD. Pathogenesis of Methicillin-Resistant Staphylococcus aureus Infection. Clin Infect Dis 2008; 46 (suppl 5):350-359.

5. Zurita J, Medjía C, Guzmán-Blancos M. Epidemiology and surveillance of methicillin resistant Staphylococcus aureus in Latin America. Braz I Infect Dis 2010; 14 (suppl 2):79-86.

6. Alvarez C, Labarca J, Salles M. Prevention strategies for methicillin-resistant Staphylococcus aureus (MRSA) in Latin America. Braz J Infect Dis 2010; 14 (suppl 2):107-118.

7. Howell-Jones, RS, Price PE, Howard AJ, Thomas DW. Antibiotic prescribing for chronic skin wounds in primary care. Wound Rep Reg 2006; 14:387-393.

8. Kirketerp-Moller K, Jensen PO, Fazli M, Madsen GK, Pedersen J, Moser C, et al. Distribution, organization, and ecology of bacteria in chronic wounds. J Clin Microbiol 2008; 46:2717-2722.

9. Delialioglu N, Aslan G, Ozturk C, Baki V, Sen S, Emekdas G. Inducible clindamycin resistance in Staphylococci isolated from clinical samples. J Infect Dis 2005; 58:104-106.

10. Fokas S, Fokas S, TsironiM, Kalkami M, Dionysopouloy M. Prevalence of inducible clindamycin resistance in macrolide-resistant Staphylococcus spp. Clin Microbiol Infect Dis 2005; 11:337-340.

11. Amorim DMR, Person OC, Amaral PJ, Tanaka II. Resistência induzível à clindamicina entre isolados clínicos de Staphylococcus aureus. O Mundo da Saúde 2009;33:401-405.

12. Gardner SE, Frantz RA, Saltzman CL, Dodgson KJ Staphylococcus aureus is associated with high microbial load in chronic wounds. Wounds 2004; 16:251-257.

13. Miller CN, Carville K, Newall N, Kapp S, Lewin G, Karimil, Santamaria N. Assessing bacterial burden in wounds: comparing clinical observation and wound swabs. Internat Wound J 2010; 8:45-55.

14. Elaine $P$, Ferreira E, Marques A, Matos B. Infecções associadas aos cuidados de saúde e segurança do doente. Rev Port Saude Publica 2010; 10:27-39.

15. Levine NS, Lindberg RB, Mason AD, Pruitt Jr BA. The quantitative swab culture and smear: a quick, simple method for determining the number of viable aerobic bacteria on open wound. J Trauma 1976; 16:89-94.

16. Angel DE, Lloyd P, Carville K, Santamaria N. The clinical efficacy of two semi-quantitative wound-swabbing techniques in identifying the causative organism(s) in infected cutaneous wounds. Internat Wound J 2011; 8:176-185.

17. Oplustil CP, Zoccoli CM, Tobouti NR, Sinto SI. Procedimentos básicos em microbiologia clínica. Editora Sarvier: São Paulo; 2010.

18. Koneman, EW, Woods GL, Procop GW, Schreckenberger PC, Allen SD, Janda WM. Diagnóstico microbiológico - texto e atlas colorido. $7^{\text {nd }}$ edition, Medsi: Rio de Janeiro; 2008.
19. Rossi F, Andreazzi DB. Resistência bacteriana - interpretando o antibiograma. Editora Atheneu: São Paulo; 2005. p. 118.

20. Clinical and Laboratory Standards Institute(CLSI). Methods for Dilution Antimicrobial Susceptibility Tests for Bacteria that grow Aerobically, Approved Standard. $18^{\text {th }}$ edition. M7-A8, M100-S21, Wayne, PA: USA, 2009.

21. National Committee for Clinical Laboratory Standards (NCCLS). Performance Standards for Antimicrobial Disk Susceptibility Tests, Approved Standard. $8^{\text {nd }}$ edition. M2-A8, Wayne, PA: USA, 2003.

22. British Society for Antimicrobial Chemotherapy (BSAC). Methods for Antimicrobial Susceptibility Testing 2009; 8:91.

23. Martins MA, Tipple AFV, Reis C, Santiago SB, Bachion MM. Úlcera crônica de perna de pacientes em tratamento ambulatorial: análise microbiológica e de suscetibilidade antimicrobiana. Cienc Cuid Saude 2010; 9:464-470.

24. Ferreira AW, Vasconcelos WS, Ferreira CM, Silva MFP, Gomes JS, Alecrim MGC. Prevalência de Staphylococcus aureus meticilina resistente (MRSA) em pacientes atendidos em ambulatório de dermatologia geral em Manaus-Amazonas. Rev Patol Trop 2009; 38:83-92.

25. Kobayashi CCBA, Sadoyama G, Vieira JDG. Determinação da resistência antimicrobiana associada em isolados clínicos de Staphylococcus aureus e Pseudomonas aeruginosa em um hospital público de Goiânia, Estado de Goiás. Rev Soc Bras Med Trop 2009; 42:404-410.

26. Kim HB, Jang HC, Nam H, Lee YS, Kim BS, Park WB, et al. In vitro activities of 28 antimicrobial agents against Staphylococcus aureus isolates from Tertiary-care hospitals in Korea: a nationwide survey. Antimicrob Agents Chemother 2004; 48:1124-1127.

27. Rossi F, Garcia P, Ronzon B, Curcio D, Dowzick MJ. Rates of antimicrobial resistance in Latin America (2004-2007) and in vitro Activity of the Glycylcycline Tigecycline and of Other Antibiotics. Braz J Infect Dis 2008; 12:405-415.

28. Luna CM, Rodríguez-Noriega E, Bavestrello L, Gotuzzo E. Treatment of methicillinresistant Staphylococcus aureus in Latin America. Braz J Infec Dis 2010; 14:119-127.

29. Quege GE, Bachion MM, Lino-Junior RSL, Lima ABM, Ferreira OS, Santos QR, et al.Comparação da atividade de ácidos graxos essenciais e biomembranana microbiota de feridas crônicas infectadas. Rev Eletr Enf 2008; 10:890-905.

30. Graffunder EM, Venezia RA. Risk factors associated with nosocomial methicillinresistant Staphylococcus aureus (MRSA) infection including previous use of antimicrobials. J Antimicrob Chemother 2002; 49:999-1005.

31. Rigatti F, Tizotti MK, Horner R, Domingues VO, Martini R, Letícia EM, et al. Bacteremias por Staphylococcus coagulase negativos oxacilina resistentes em um hospital escola na cidade de Santa Maria, Estado do Rio Grande do Sul. Rev Soc Bras Med Trop 2010; 43:686-690.

32. Sousa-Júnior FC, Néri GS, Silva AK, Araújo BPRC, Guerra MJPD, Fernandes MJBC, et al. Evaluation of different methods for detecting methicillin resistance in Staphylococcus aureus isolates in a university hospital located in the northeast of Brazil. BMJ 2010; 41:316-320.

33. Keim LS, Torres-Filho SR, Patricia VS, Lenise AT. Prevalence, aetiology and antibiotic resistance profiles of coagulase negative Staphylococci isolated in a teaching hospital. Braz J Microbiol 2011; 42:248-255.

34. Baraboutis I G, Tsagalou EP, Papakonstantinou I, Marangos MN, Gogos C, Skoutelis AT, et al. Length of exposure to the hospital environment is more important than antibiotic exposure in healthcare associated infections by methicillin-resistant Staphylococcus aureus: a comparative study. Braz J Infect Dis 2011; 15:426-435.

35. Liu C, Bayer A, Cosgrove, SE, Daum RS, Fridkin SK, Gorwitz RJ, et al. Clinical Practice Guidelines by the infectious diseases society of America for the treatment of methicillin-resistant Staphylococcus aureus infections in adults and children. CID 2011; 52:18-55.

36. Tavares W. Antibióticos e quimioterápicos para o clínico. Editora Atheneu: São Paulo; 2009. p. 599.

37. Lima ALLM, Oliveira PRD. Recomendações para o manejo das infecções em úlceras neuropáticas das extremidades inferiores. Bevilacqua Editora: São Paulo; 2011. p. 14.

38. O'Meara S, Al-Kurdi D, Ologun Y, Ovington LG. Antibiotics and antiseptics for venous leg ulcers. Cochrane Database Syst Rev 2010; 1:1-35.

39. Robson MC, Cooper DM, Aslam R, Gould LJ, Harding KG, Margolis DJ, et al. Guidelines for the treatment of venous ulcers. Wound Rep Reg 2006; 14:649-662.

40. Davies CE, Hill KE, Newcombe RG, Stephens P, Wilson MJ, Handing, KG et al. A prospective study of the microbiology of chronic venous leg ulcers to reevaluate the clinical predictive value of tissue biopsies and swabs. Wound Rep Rep 2007; 15:17-22. 